Tạp chí Khoa học và Công nghệ biển T10 (2010). Số 2. Tr 01 - 13

\title{
VẤN ĐỀ BỒI LẤP Ở CÁC CỬA BIỂN SA HUỲNH (QUẢNG NGÃI), TAM QUAN VÀ ĐỀ GI (BÌNH ĐỊNH) DO TÁC ĐộNG CỦA CÁC KIỂU KÈ MỎ HÀN
}

\author{
PHẠM BÁ TRUNG, LÊ ĐÌNH MẦU, LÊ PHƯớC TRÌNH \\ Viện Hải dương học
}

\begin{abstract}
Tóm tắt: Bài báo cung cấp một số thông tin về hiện trang và tác động bồi lấp của các kè bảo vệ các của biển Sa Huỳnh (Quảng Ngãi); Tam Quan và Đề Gi (Bình Định) qua số liệu khảo sát thực địa. Kết quả nghiên cứu cho thấy các tác động bồi lấp của các kè mỏ hàn tại ba cưa biển trên là giống nhau. Biện pháp xây đắp kè trước cưa đã dẫn đến một số thay đổi trong co chế thủy thạch động lực tại vùng cửa biển, kèm theo là thay đổi quá trình lắng đọng vật liệu bồi lấp cưa, các quá trình thủy thạch động lực này đều trở nên phức tạp hơn gây trở ngại nhiều hơn với nhũng gì đã có, hiệu quả khắc phục bồi lấp.
\end{abstract}

\section{I. ĐẶT VẤN ĐỀ}

Các cửa biển Sa Huỳnh (tỉnh Quảng Ngãi), Tam Quan và Đề Gi (tỉnh Bình Định) có ý nghĩa kinh tế - xã hội rất quan trọng ở khu vực miền Trung. Ở những nơi này, có các đầm Nước Mặn (Sa Huỳnh, diện tích 130 ha), vụng Tam Quan (khoảng 20 ha) và đầm Nước Ngọt (Đề Gi, khoảng 1300 ha). Đó là những chỗ neo đậu cho tàu thuyền rất lý tưởng mà hằng năm có hàng ngàn tàu đánh cá ra vào qua mỗi cửa. Tuy nhiên, nạn bồi lấp cửa thường xuyên gây khó khăn cho sự lưu thông ấy. Mấy năm gần đây nghề đánh bắt xa bờ, câu cá ngừ Đại dương phát triển mạnh, số lượng các tàu có công suất lớn cần ra vào cửa nhiều hơn, số lượng tàu thuyền các cỡ tăng đáng kể, vai trò của các cửa biển này do đó càng trở nên quan trọng hơn rất nhiều. Nhưng kèm theo đó khó khăn trở ngại cũng tăng lên vì các loại tàu thuyền này hầu như không ra vào được, hiện tượng bồi lấp cửa biến đổi ngày càng phức tạp cho dù đã có nhiều biện pháp ngăn chặn.

- Vấn đề bồi lấp các cửa Sa Huỳnh, Tam Quan và Đề Gi đã có từ lâu đời. Khoảng mười năm trở lại đây cộng đồng ngư dân và chính quyền ở các địa phương đã cố gắng đắp các kiều kè mỏ hàn nhằm ngăn chặn luồng cát bồi dẫn tới cửa, Nhưng cho đến nay nạn bồi lấp vẫn chưa giải quyết được, thậm chí từ khoảng 4 - 5 năm nay, tình hình còn nghiêm trọng hơn. Chúng tôi nhận ra rằng biện pháp xây đắp kè trước cửa mà các địa phương đã làm dẫn đến một số thay đổi trong cơ chế thủy động lực vùng cửa biển, kèm theo là thay 
đổi quá trình lắng đọng vật liệu bồi lấp cửa, các quá trình thủy động lực và thạch động lực đều trở nên phức tạp hơn gây trở ngại nhiều hơn.

Do vậy, trong bài báo này chúng tôi phân tích hiện tượng bồi lấp các cửa biển đã và đang xảy ra, chúng tôi tập trung vào ba cửa biển Sa Huỳnh, Tam Quan và Đề Gi.

\section{TÀI LIÊU VÀ PHƯƠNG PHÁP NGHIÊN CÚU}

\section{Thu thập tài liệu}

- Đề tài cấp Nhà nước KC.06.08: "Nghiên cứu hiện trạng, qui luật xói lở bồi tụ dải ven biển và cửa sông Việt Nam", (1997-2000) [1] [2].

- Đề tài hợp tác Việt Nam - Ân Độ: "Nghiên cứu hiện trạng, qui luật xói lở bồi tụ tại khu vực Cửa Đại, Hội An" (2003).

- Đề tài cấp Viện KH\&CN VN: "Đánh giá những tác động của các công trình bảo vệ đến môi trường vùng cửa sông ven biển Nam Trung bộ", (2008 - 2009).

- Nguồn ảnh viễn thám đa thời gian: Đã sử dụng bộ dữ liệu ảnh viễn thám vào các thời kỳ khác nhau.

- Tài liệu của các chuyến khảo sát: Đà Nẵng - Bình Thuận (7/2008 và 11/2008).

\section{Phương pháp nghiên cứu}

- So sánh, đánh giá các kết quả khảo sát thực tế với kết quả phân tích ảnh Viễn thám.

- Chuyển đổi về hệ lưới chiếu thống nhất Mercator - WGS 84.

- Chuyển đổi từ định dạng raster sang vector để số hóa tự động đường bờ vào các thời điểm khác nhau.

\section{KẾT QUẢ NGHIÊN CÚU}

\section{Hình thái đường bờ khu vực cửa Sa Huỳnh, Tam Quan, Đề Gi}

- Vùng bờ biển từ Sa Huỳnh - Quy Nhơn khúc khuỷu là đoạn bờ tích tụ mài mòn đang bị san bằng, có nhiều bãi biển và các doi cát nối đảo kiểu Tombolo xen kẽ các lagoon ven bờ. Đoạn bờ này là giai đoạn kế tiếp của giai đoạn vũng vịnh mài mòn do sự phát triển mạnh mẽ của các dạng tích tụ ở các đỉnh vũng vịnh nhỏ, với sự hiện diện của vịnh Quy Nhơn, đầm Đề Gi và đầm Thị Nại làm cho cảnh quan vùng bờ trở nên đa dạng hơn. Quá trình phát triển của đoạn bờ này chịu tác động mạnh mẽ của sông Côn, sông Lại Giang và 
quá trình vận chuyển ngang bồi tích do tác động của sóng. Bên cạnh đó còn có khá nhiều vũng vịnh nhỏ với kích thước $\leq 100 \mathrm{~km}^{2}$, độ sâu trung bình khoảng $20 \mathrm{~m}$, là những nơi trú ngụ tàu thuyền nhỏ rất thuận lợi. Đặc biệt vai trò của ba cửa Sa Huỳnh (Quảng Ngãi), Tam Quan và cửa Đề Gi (Bình Định) (hình $1,2,3$ ) là rất lớn, nhờ chúng mà nghề đánh cá ở khu vực miền Trung khá phát đạt, nhất là những năm gần đây ngành đánh bắt xa bờ phát triển mạnh. Bên trong ba cửa này có các đầm nước ngọt, nước mặn rộng và tương đối sâu làm nơi tập kết tàu thuyền đánh cá rất thuận lợi. Nối giữa đầm và vịnh là những eo cửa hẹp và ngắn (không phải hạ lưu sông), nước chảy yếu, bờ Bắc eo cửa không biến động. Đây là các luồng ra vào của ghe thuyền.

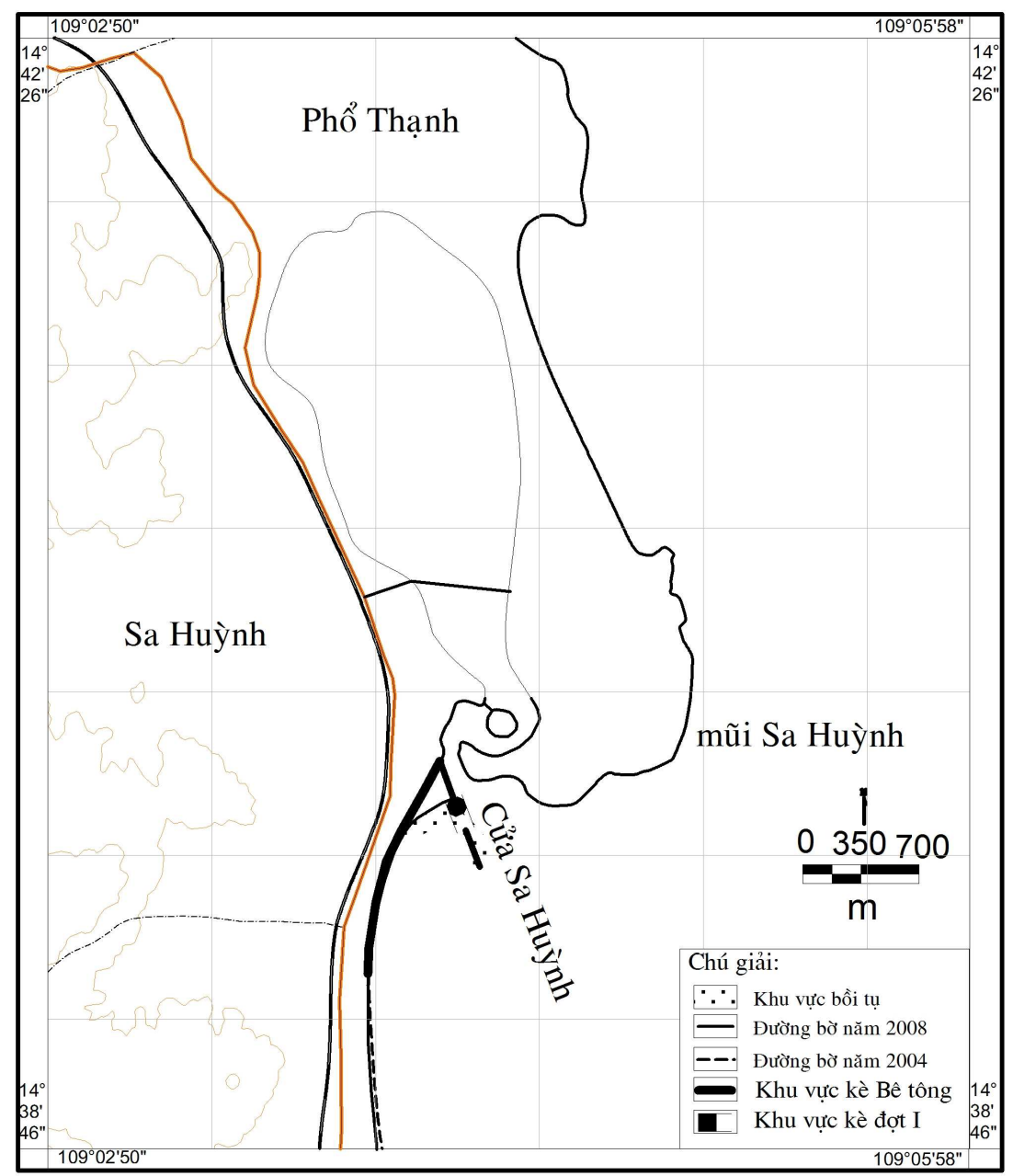

Hình 1: Sơ đồ hiện trạng bồi tụ - xói lở và công trình kè ở cửa Sa Huỳnh

Cần nhấn mạnh rằng địa hình khu vực và vị trí cửa, điều kiện tự nhiên, cơ chế thủy thạch động lực và những biểu hiện bồi lấp cửa, những khó khăn thực tế do bồi lấp gây ra, ở ba cửa biển này đều tương đồng nhau, cho nên kết quả nghiên cứu và phân tích ở một 
nơi này cũng là đại diện cho một nơi khác. Địa hình phía trong mặt cắt cửa ở cả ba nơi là đầm tương đối kín thông ra biển bằng một eo nước hẹp và ngắn nên chúng tôi thường gọi là "eo cửa " (tiếp giáp bên trong mặt cắt cửa), trong eo dòng chảy yếu và không ổn định. Có một rãnh sâu phía tả ngạn tựa vào bờ Bắc kéo dài từ eo cửa ra từ mũi Đông - Bắc vịnh, đó thường là luồng qua lại của tàu thuyền từ đầm ra tới biển khơi, chúng tôi gọi là "luồng lưu thông". Bờ Bắc cửa biển là những dảy núi đá cao và dài nhô ra biển và quá trình xói lở - bồi tụ cũng ít xảy ra. Bờ Nam cửa lại là vùng đất cát dễ thay đổi dưới tác động của dòng chảy ven bờ, đặc biệt là tác động sóng. Địa hình ở đây có dạng mũi cát nên thường gọi là "mũi Nam cửa", trên đó là khu dân cư, ở chỗ sát biển, mũi hay bị thay đổi do sóng xói nhưng thường là được bồi lên thành đụn cát cao và rộng.

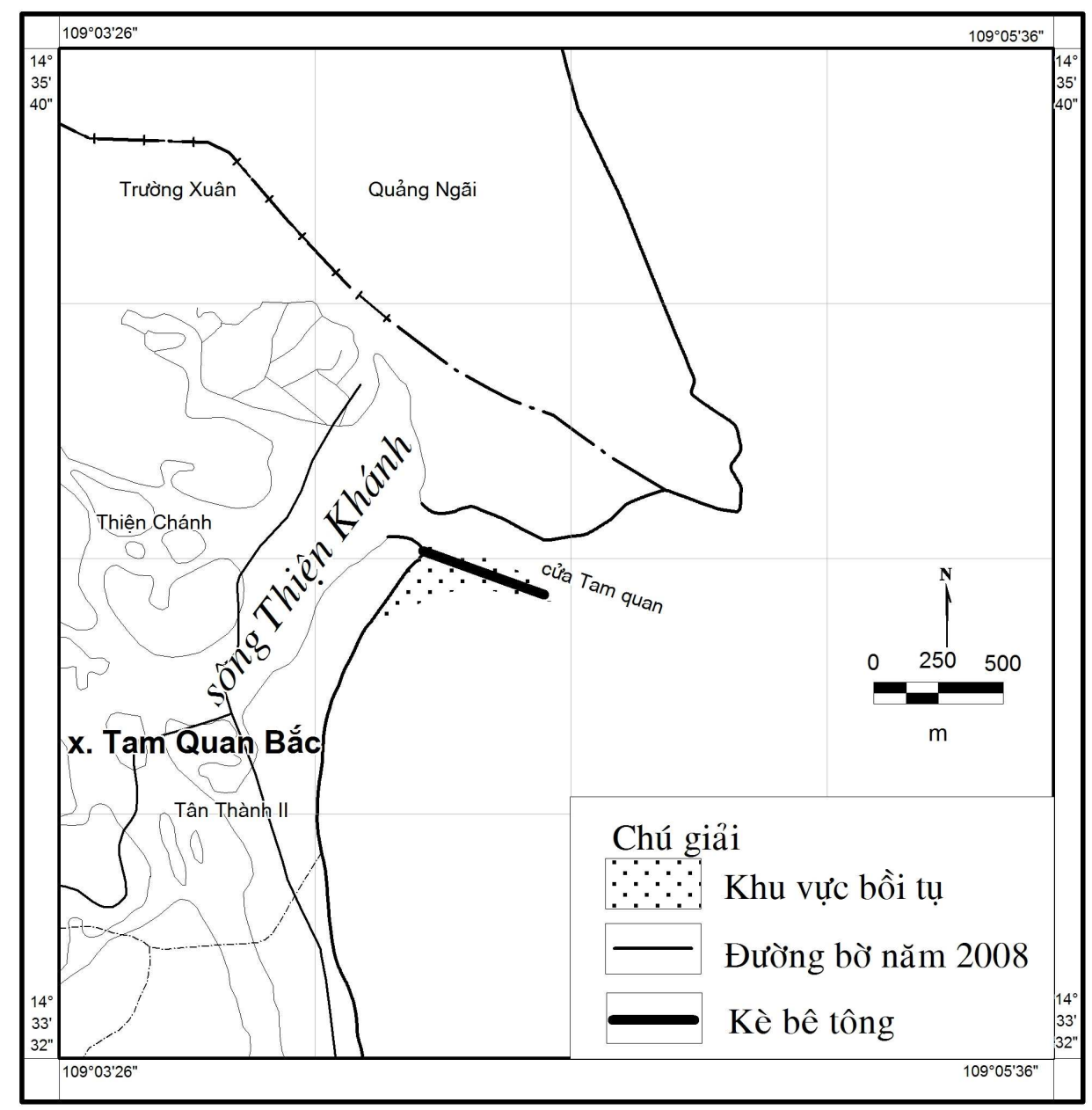

Hình 2: Sơ đồ hiện trạng bồi tụ - xói lở và công trình kè ở cửa Tam Quan 


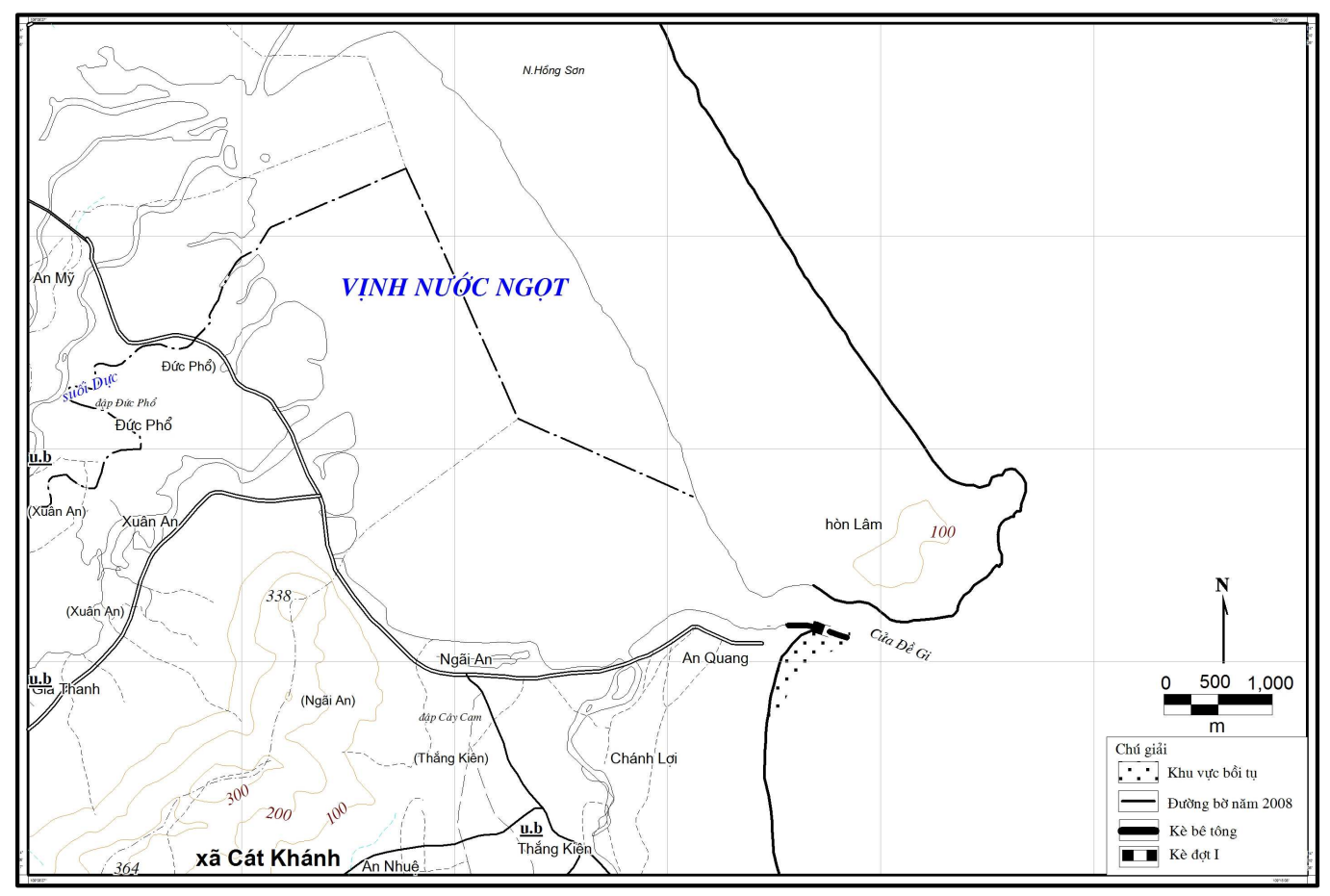

Hình 3: Sơ đồ hiện trạng bồi tụ - xói lở và công trình kè ở cửa Đề Gi

\section{Tác động thủy thạch động lực từ các kiểu kè trước cửa sông}

\subsection{Các biểu hiện bồi lắng trước cửa ở các cửa Sa Huỳnh và Đề Gi}

Cơ chế vận chuyển vật liệu dọc bờ và khả năng tích tụ một cách tập trung hàm lượng vật liệu đưa đến bồi lấp cửa. Sau đây là một số hình ảnh ghi nhận được về bồi lấp tại hiện trường (hình 1,2 và ảnh $1,2,3,4$ ) cho thấy một dải bồi lắng và tích tụ vật liệu trước $\mathrm{Sa}$ Huỳnh, cửa Đề Gi. Trong điều kiện bình thường của tự nhiên, tức là chưa có các biện pháp mà con người can thiệp vào, hình thái của sự lắng đọng và tích tụ vật liệu ở khu vực trước cửa thể hiện bằng một dải dài vòng cung theo vết của quá trình chuyển hướng luồng dòng chảy. Ta có thể nhận ra rằng luồng dọc bờ Nam - Bắc là nguyên nhân tạo ra dải bồi lắng trước cửa, và ngược lại, dải bồi lắng đó chứng tỏ về sự hiện diện của luồng dọc bờ vịnh. Cơ chế thủy-thạch động lực này là gốc của vấn đề bồi lấp cửa tại Sa Huỳnh, Tam Quan và Đề Gi.

Quá trình lắng đọng và tích tụ vật liệu và bồi tích cũng có hai dạng. - Một dạng lắng đọng trong quá trình vận chuyển của cấu trúc luồng. Dòng chảy trực tiếp mang theo vật liệu đáy và vật liệu lơ lửng dọc bờ từ Nam lên, đến khu vực vòng cung trước cửa do tốc độ dòng yếu đi đồng thời với chuyển hướng véctơ nên vật liệu có điều kiện lắng đọng lại và phân bố thành dải dài bên ngoài cửa. (ảnh $1,3,4$ ), - Một dạng khác, một phần vật liệu 
mang theo luồng được tích tụ một cách tập trung ngay trên mép bờ ở mũi phía Nam cửa (góc hữu ngạn dòng là từ trong đầm ra) (ảnh 2). Dạng này được hình thành chủ yếu do ảnh hưởng lõm thủy lực từ luồng chảy Nam - Bắc khi gặp phải mặt cắt cửa. Nói rõ hơn, trong eo cửa dòng chảy không mạnh, điểm đầu phía Nam của mặt cắt cửa là điểm hẫng hụt áp lực nước trong quá trình tiếp xúc của luồng chảy Nam - Bắc với bờ vịnh. Theo qui luật tại đây xảy ra sự ngưng trệ chuyển động nước, chuyển động rối loạn, cùng với tính chất bất thường của dòng chảy bên trong eo cửa, tất cả những yếu tố bất ổn định tập hợp lại thành điều kiện thuận lợi lôi cuốn mạnh lượng vật liệu bồi tích có trong luồng vào rồi lắng đọng tại một khu vực hẹp trước mũi. Về mùa gió Đông - Bắc, sóng lớn vỗ bờ góp phần đẩy lượng cát đã lắng đọng thành đụn cao hay bãi rộng tại đây. Ở đây cần lưu ý, sóng vỗ chỉ đẩy nhanh quá trình bồi thành bãi và đụn cao chứ không phải là nguyên nhân vận chuyển lượng cát và vật liệu bồi đến đây. Từ các đụn và bãi ở góc bờ Nam một lượng lớn cát bồi sẽ lan dần ra mặt cắt cửa và eo cửa góp phần tạo thành quá trình bồi lấp ở đó.
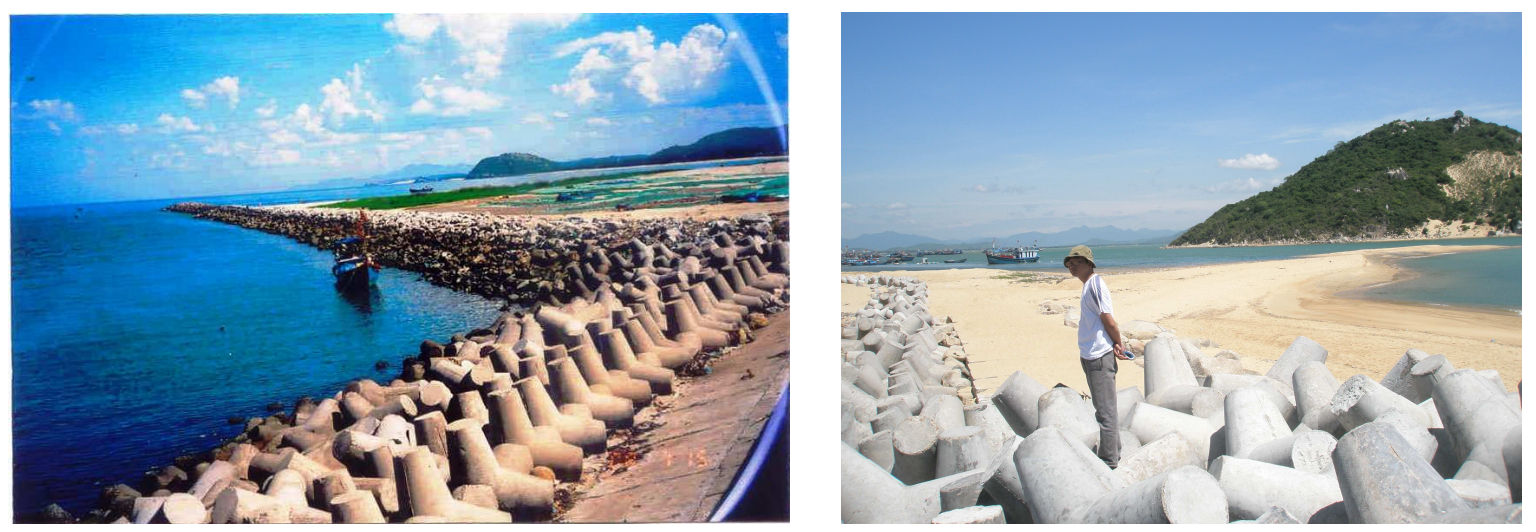

Ảnh 1: Bãi bồi ở phía Nam cửa Sa huynh

Ảnh 2: Doi cát bồi lắp ở phía trong cửa Đề Gi

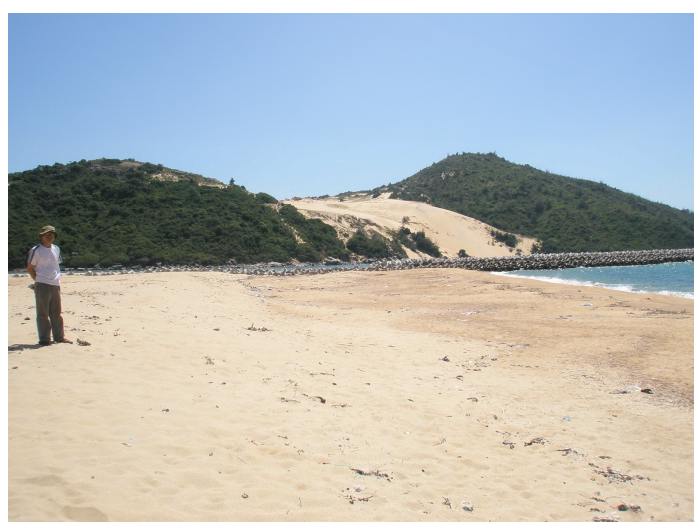

Ảnh 3: Bãi bồi ở phía Nam cửa Đề Gi

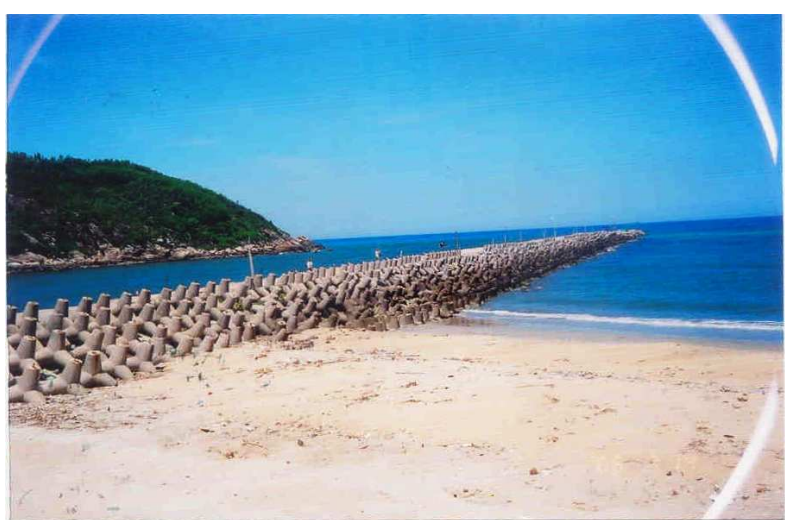

Ảnh 4: Bãi bồi ở phía Nam cửa Tam Quan 
Tóm lại, luồng chảy mạnh Nam - Bắc dọc bờ vịnh là nguyên nhân chính tạo thành dải bồi tích vòng quanh trước cửa, đồng thời là nguyên nhân thu hút và tích tụ một cách tập trung lượng bồi tích vào các bãi tại mũi phía Nam cửa, hình thành đụn cát cao, lan dần ra bồi lấp cửa và eo cửa. Muốn chống bồi lấp cửa thì hiển nhiên là phải chống luồng chảy và luồng vật liệu kèm theo. Thông thường, kè mỏ hàn chính là biện pháp hữu hiệu. Tuy nhiên, trước khi dựng kè ta cần phải hiểu điều gì sẽ xảy ra một khi kè chắn ngang cả bề rộng hay một phần luồng chảy.

\subsection{Dụng kè mỏ hàn - nhũng cố gắng đầu tiên chống bồi lấp cửa}

Phần lớn ngư dân trong các khu vực cửa đều thông hiểu quá trình vận chuyển vật liệu cát dọc bờ từ phía Nam lên gây bồi lấp cửa biển, chính vì vậy để chống bồi lấp tại mỗi nơi họ đã tiến hành hai đợt xây dựng kè mỏ hàn chắn các luồng này. Đợt I vào khoảng năm 1999, kè ngắn $(70-100 \mathrm{~m})$ cùng với kỹ thuật dựng kè đơn giản là xếp đá tảng chồng lên nhau có hỗ trợ kết dính bằng xi-măng nhưng rất thô sơ (Sa Huỳnh) hoặc đá tảng xen lẫn các mố bê-tông 4 ngạnh (Đề Gi). Đợt II vào năm 2006 - 2007, kè được nối dài ra đến khoảng 200 - $250 \mathrm{~m}$ với kỹ thuật cũ nhưng có phần kiên cố hơn. Tuy nhiên trong cả hai đợt kết quả đem lại không như ý, tình hình bồi lấp cửa vẫn diễn ra còn phức tạp hơn. Qua tư liệu các đợt khảo sát (hình 1,2).

a) Kè đọt I, đắp vào khoảng năm 1999: Kè mỏ hàn dài khoảng $70 \mathrm{~m}$ ở Sa Huỳnh và $100 \mathrm{~m}$ ở Đề $\mathrm{Gi}$, nằm cách mặt cắt cửa chừng $50 \mathrm{~m}$ ngược về phía đầu luồng (tức phía Nam), chắn ngang một phần bên trái (sát bờ) của luồng chảy. Đó là những kè mỏ hàn đầu tiên hoàn toàn do nhân dân đầu tư và thực hiện.

Sau khi kè đợt I phát huy tác dụng, trong vòng 1 - 2 năm (2000), tại Sa Huỳnh chúng tôi đã ghi nhận một số biểu hiện như sau. Biểu hiện thứ nhất, cát bồi cao lên đến xấp xỉ mặt nước, bao trùm cả phần không gian trước kè (hướng tác động trực tiếp của luồng chảy). Cát bồi còn tràn và xuyên qua kè lấp thêm phần không gian phía sau kè. Biểu hiện thứ hai là, tác động sóng trong mùa gió Đông - Bắc tập trung vào đây đã đẩy cát vào sát bờ hình thành đụn cát cao ở mũi phía Nam cửa, từ đó lan truyền ra phía mặt cắt cửa và eo cửa. Cát trườn vào và tụ lại ở bờ phía Nam tạo thành một dải cát bồi hẹp men theo bờ Nam eo, ngược lại, bờ phía Bắc thì hoàn toàn hằm dài theo chân núi (luồng lưu thông lệch về phía bờ bắc). Nhìn chung, sau kè đợt I hiện tượng bồi lấp cửa vẫn diễn ra mạnh, tập trung ở mũi Nam cửa và bờ Nam eo cửa. Lưu thông thuyền bè vẫn khó khăn, thậm chí còn khó hơn trước do nhiều biến đổi phức tạp. Theo phản ảnh của ngư dân địa phương thì quá trình bồi bây giờ rất nhanh, có lẽ là vì lượng vật liệu trôi dạt bị chặn và đọng lại ở vùng cửa nhiều hơn trước. 
Ở Đề Gi, các biểu hiện bồi lấp và biến đổi do kè đợt $\mathrm{I}$ tạo ra là hoàn toàn tương tự như ở Sa Huỳnh nhưng có phần mãnh liệt hơn, rõ ràng hơn. Trên hình 1, 2 ta thấy đoạn kè mỏ hàn đợt I (các mố bê-tông 4 ngạnh bị lấp ở nửa phía trong) bị lấp gần hết, phía trước kè là đụn cát bồi cao lên quá mặt nước gần một mét và chiếm toàn bộ chiều dài kè. Cát bồi vượt qua kè, một mặt phát triển lạnh ra hướng eo cửa, mặt khác lại men theo bờ Nam của eo làm thành dải cát hẹp ven bờ phía Nam. Như vậy là ở đáy kè mỏ hàn đợt I này cũng không ngăn cản được nạn bồi lấp ngư dân cũng vẫn bức xúc vì lất khó ra vào cửa.

Nguyên nhân tình trạng kéo dài nạn bồi lấp cửa và biến đổi phức tạp sau tác động của kè đợt I, do cơ chế động lực được tạo ra bởi kè chắn luồng. Kè mỏ hàn ngắn đợt I tiếp giáp và trực giao với bờ, dài khoảng $70 \mathrm{~m}$. Tập hợp những biến dạng của hoàn lưu do tác động của kè như sau: - Trước tác động của kè là đoạn luồng Nam - Bắc ven bờ vịnh, đó đơn giản là một bộ phận của hoàn lưu xoáy cục bộ, chưa có thay đổi gì; - Trong tác động là đoạn luồng dọc trước kè mỏ hàn. Đoạn luồng này bảo đảm tính liên tục của hệ dòng chảy trong vịnh đồng thời được tăng cường bởi thành phần có nguồn gốc từ hiệu ứng dao động va đập khi luồng chính từ phía Nam tác động lên mặt trước của kè; - Sau tác động là đoạn phân nhánh luồng ở cuối kè thành hai, Ở đây, một nhánh có hướng vòng và đâm trực tiếp vào mặt cắt cửa, phát triển sâu vào trong eo cửa bên hữu ngạn (nên nhớ dòng chảy trong eo khá yếu). Còn nhánh kia có hướng lệch ra xa so với mặt cắt cửa nhưng cũng hướng về phía luồng lưu thông dọc theo bờ Bắc.

Cơ chế thủy động lực đó kéo theo đặc điểm vận chuyển và lắng đọng bồi tích. vùng có vật liệu bồi lắng do các luồng nước mang theo dưới tác động kè mỏ hàn đợt I. Ta lưu ý hai đặc điểm: Một là, lượng vật liệu lớn đọng lại tại góc đầu kè (sát bờ) và sau đó giản dần ra trên mép trước kè. Dễ hiểu là lượng vật liệu đọng lại ở hai khu vực này được tăng lên đáng kể so với trường hợp bình thường bị kè chặn lại. Trên thực tế chúng tôi cũng đã ghi nhận được hình ảnh dồn cát thành bãi rộng ở không gian trước kè (ảnh $1,3,4)$. Từ đây dưới tác động của hiệu ứng va đập và các đợt sóng một lượng cát nhất định được lan truyền và thẩm thấu sang phần không gian sau kè. Hai là (quan trọng nhất), hai dải bồi men theo hai nhánh luồng chảy ở cuối kè. Một nhánh được vận chuyển đưa vào lắng đọng ngay tại cửa, lan truyền vào trong eo, có xu hướng lệch về bờ Nam eo cửa. Cùng với các bãi bồi ở mũi Nam cửa, nhánh bồi tích này là nhân tố rất quan trọng làm tăng hàm lượng bồi lấp về phía bờ Nam cửa và eo cửa. Một nhánh vật liệu nữa vận chuyển, có xu hướng giản về phía ngoài khơi qua tả ngạn luồng lưu thông phía bờ Bắc. Trên thực tế nhánh này cũng tạo ra một phần sự cản trở lưu thông thuyền bè nhưng không lớn bằng nhánh kia.

b) Kè đọt II, đắp vào năm 2006 - 2007: Trung thành với nguyện vọng và ý tưởng chống bồi lấp cửa bằng biện pháp kè mỏ hàn người ta đã đắp tiếp kè mỏ hàn đợt I dài thêm ra khoảng gần 150 mét nữa, cao hơn, cấu trúc chắc chắn hơn do có pha thêm nhiều cấu 
kiện mố bê-tông 4 ngạnh và xi măng. Nhìn bề ngoài kè đợt II vững chải hơn, kinh phí đổ vào đây chắc cũng tăng lên rất nhiều. Kè Sa Huỳnh bây giờ dài khoảng hơn $200 \mathrm{~m}$, mũi phía Nam cửa đã được kiên cố hóa bằng bêtông cột thép dày và khá cao (khoảng $1 \mathrm{~m}$ cao hơn mặt đất, $2 \mathrm{~m}$ cao hơn mặt nước) chạy dọc theo bờ từ phía trong eo lưu thông ra đến đầu kè. Kè Đề Gi cũng vậy, cấu trúc khá vững chải, duy không được bê-tông hóa dọc bờ mũi Nam cửa như ở Sa Huỳnh.

Nhận định tổng quát ban đầu cho cả hai cửa Sa Huỳnh và Đề Gi sau kè đợt II là nạn bồi lấp cửa cản trở lưu thông vẫn xảy ra, thậm chí còn nghiêm trọng hơn, biến hóa phức tạp hơn. Trong đợt khảo sát tháng 7/2008 chúng tôi đã ghi nhận nhiều hình ảnh về điều đó đồng thời tìm hiểu trong dân được biết khó khăn vẫn còn đó. Các biểu hiện bồi lấp bây giờ thể hiện như sau.

Tại Sa Huỳnh, đặc điểm lắng đọng vật liệu và bồi lấp cửa sau tác động của kè đợt II có một số biến đổi so với kè đợt $\mathrm{I}$. Đặc điểm quan trọng và rõ ràng nhất là sự bồi lắng gần như chuyển hắn về nửa phần phía Bắc cửa, dọc theo rìa dảy núi đá bên kia mũi. Ở đây đã xuất hiện dải cát bồi hẹp men theo bờ kể từ bên ngoài cửa xuyên qua eo và vào đến khu vực đầm nước có tàu thuyền lưu đậu. Do vậy, mặc dù nạn lan truyền vật liệu từ các đụn cát ở mũi Nam cửa ra eo đã bị chặn đứng bởi kè bê-tông kiên cố dọc bờ mũi nhưng eo cửa vẫn trở nên hẹp và cạn hơn Hiện tại người ta phải tổ chức nạo vét luồng ra vào cửa - động tác mà trước đây chưa cần tới. Trong chuyến khảo sát chúng tôi thấy một chiếc xà lan hút cát lớn đang hoạt động. Theo người dân nói, chiếc xà lan này làm việc liên tục ngày-đêm, chủ yếu ở dọc bờ Bắc eo cửa (tả ngạn) và chỉ rút đi khi mùa sóng lớn đến, còn lượng tàu thuyền ra vào cửa và neo đậu trong đầm trở nên ít đi đáng kể. Một đặc điểm nữa là dưới tác động của kè đợt II, chỉ trong vòng 1 - 2 năm một bãi cát rộng đã nổi lên thành bãi cỏ chiếm phần lớn không gian trước kè, bãi cỏ đã lan ra đến gần mút cuối kè. Cũng từ đây một lượng cát nhất định tiếp tục lan ra bồi lấp eo cửa.

Tại Đề Gi, do không xây kè kiên cố bao bọc mũi Nam cửa nên các đụn cát ở đây (từ kè đợt I) vẫn tiếp tục phát triển về kích thước. Song, giống như ở Sa Huỳnh, đặc điểm quan trọng nhất vẫn là ảnh hưởng trong cơ chế phân nhánh luồng ở mút cuối kè đợt II làm cho hiện tượng bồi lấp lệch hơn về phía bờ Bắc eo cửa. Tại cửa Đề Gi nhánh này đã tạo ra một dải cát bồi ngầm mới kéo dài vào đến tận trong không gian của eo cửa. Dải bồi ngầm thể hiện khá rõ. Chính sự xuất hiện dải ngầm này mà luồng lưu thông qua eo bị hẹp lại khá nhiều, chỉ còn khoảng $15 \mathrm{~m}$ và phải chịu lệch về tả ngạn. Đụn cát cao ở mũi Nam mặt cắt cửa vẫn tiếp tục phát triển ra eo cửa một cách mạnh mẽ. Như vậy, hai dải bồi ngầm và nổi sau kè đợt II tiếp tục gây khó khăn cho thuyền bè lưu thông qua cửa, ngư dân tại khu vực này cũng hoang mang không kém ngư dân tại cửa Sa Huỳnh. 
c) Kè mỏ hàn trước của biển Tam Quan: Trên đây chúng tôi chưa đề cập gì đến kè mỏ hàn ở cửa Tam Quan - Bình Định (hình 3 , ảnh 4), vì mới chỉ có một lần duy nhất khảo sát tại đây vào ngày 15/7/2008 nên chưa hình dung được có hay không sự biến đổi kè do hiện tượng bồi lấp cửa như ở hai khu vực kia, chưa nắm chắc về mục tiêu và quá trình xây dựng kè mỏ hàn ở đây. Kết quả tìm hiểu từ những cán bộ và công nhân đang làm kè tại đây về tình hình xây kè như sau.

Đã hoàn chỉnh một đoạn kè mỏ hàn dài khoảng 300 mét, kiên cố hơn kè ở Sa Huỳnh và Đề Gi. Nhưng do thiết kế mới có thay đổi nên hiện tại công trường đang chuẩn bị xây tiếp dài ra khoảng 400 - 500 mét nữa, kè sẽ có chiều dài khoảng 700 - 800 mét, các loại mố bê-tông và kết cấu bê-tông lớn đang tiếp tục chuyển về và đang đúc tại chỗ. Lý do xây dài kè ra không ai nói rõ. Vị trí và chiều dài kè tiếp xúc với luồng lưu thông sâu dọc theo hướng bờ Bắc (núi đá). Suy từ những kết quả nghiên cứu được trình bày trên đây chúng tôi thử lạm bàn kết quả của kè mỏ hàn đối với vấn đề bồi lấp cửa tại Tam Quan (nếu có) sẽ như thế nào.

Trước hết, với chiều dài 700 - $800 \mathrm{~m}$ thì liệu kè mỏ hàn ở Tam Quan đã chắc vượt qua được ảnh hưởng của luồng chảy Nam - Bắc dọc bờ vịnh hay chưa? Câu trả lời theo chúng tôi là chưa, vì một mặt kích thước luồng chưa được khẳng định, mặt khác không thể khẳng định rằng cơ chế động lực do tác động đối kháng nhau giữa luồng chảy và kè mỏ hàn sẽ bị triệt tiêu bởi chiều dài kè. Tính liên tục của hệ dòng chảy và điều kiện bảo toàn khối lượng của cả khối nước trong vịnh bảo đảm cho sự tồn tại của cơ chế ấy, đặc biệt là cơ chế tách thành hai nhánh ở cuối kè. Mô hình cấu tạo cơ chế thủy-thạch động lực trong trường hợp kè kéo dài ra hơn gấp đôi so với kè Sa Huỳnh và Đề Gi. Từ đấy ta có thể rút ra mấy nhận xét sau :

Thứ nhất và cũng là quan trọng nhất, luồng chảy Nam - Bắc vẫn phải giữ trạng thái liên tục, nghĩa là sẽ tạo vùng chuyển hướng dòng (feeder current) và sau đó men theo mặt nước kè chảy ra khơi. Dao động va đập lên toàn bộ mặt kè không những không tắt đi mà ngược lại trở nên mở rộng kích thước hơn, dòng sóng va đập được duy trì. Phần không gian phía sau kè vẫn là khu vực lõm thủy lực với đầy đủ các tính chất riêng biệt của nó. Từ đó cấu trực hai nhánh vẫn phải được hình thành ở cuối kè. Hậu quả của cơ chế thủy động lực đó chắc chắn phải kéo theo sự lan truyền vật liệu bồi tích, tuy có thể biến đổi trong chừng mực nhất định về cường độ và tính chất so với trường hợp kè ngắn (do không gian hoạt động được mở rộng ra) nhưng không có nghĩa là các đặc điểm vận chuyển và lắng đọng bồi tích có thể mất đi hoặc thay đổi thành hình thái khác được. Còn trong trường hợp kè vẫn chỉ chặn được một phần bề rộng của luồng Nam - Bắc thì cơ chế thủy-thạch cũ vẫn là cơ bản. 
Thứ hai, càng kéo dài kè mỏ hàn ra xa thì độ sâu đáy càng lớn, dẫn tới độ bền vững của kè càng thấp, mức độ khó khăn cho thi công và chi phí phải bỏ ra cho mỗi đơn vị độ dài kè càng tăng lên gấp bội. Như vậy, trong lúc hiệu quả chống bồi lấp cửa chưa có gì để chứng minh là đảm bảo thì cơ chế thủy-thạch động lực cho thấy điều ngược lại. Đó là những điểm yếu trong việc xây kè mỏ hàn tại cửa Tam Quan hiện nay.

Tóm lại, bình thường (chưa xây kè chắn) tại các vùng cửa biển $\mathrm{Sa} H u y ̀ n h$ và Đề $\mathrm{Gi}$ hiện tượng lắng đọng vật liệu mang theo luồng dọc bờ tạo thành một dải vòng cung dài phía trước các cửa và tấp vào bồi lấp cửa gây ách tắc lưu thông thuyền bè đánh cá qua eo thông thương với các đầm nước bên trong. Người ta đã xây đấp kè mỏ hàn để chồng bồi lấp, tuy nhiên không hiệu quả. Trường hợp $\mathrm{I}$, kè ngắn làm biến đổi cơ chế thủy-thạch động lực, trong đó quan trọng nhất là xuất hiện cơ chế tách luồng chảy thành hai nhánh ở cuối kè mà dòng bồi tích do chúng tạo ra ở khu vực cửa càng gây khó khăn thêm cho việc qua lại của thuyền bè. Người ta đã đẩy cơ chế này ra xa cửa hơn bằng cách kéo dài kè mỏ hàn ra gấp đôi nhưng vẫn không mang lại kết quả như mong muốn. Nguyên nhân là do chưa ngăn chặn được tác động của toàn bộ cơ chế thủy-thạch động lực, đặc biệt là cơ chế tách luồng thành hai nhánh ở cuối kè. Dù có tiếp tục đẩy cơ chế này ra xa bờ thêm nữa như đã làm ở Tam Quan thì, theo phân tích của chúng tôi, cũng không giải quyết tận gốc nạn bồi lấp cản trở lưu thông thuyền bè qua cửa. Vấn đề đặt ra là phải thay đổi phương án xây dựng kè cho hợp lý hơn những phương án đã làm.

\section{KẾT LUẬN}

Tại các cửa $\mathrm{Sa}$ Huỳnh, Tam Quan và Đề Gi luồng chảy dọc bờ vịnh có hướng từ Nam lên Bắc, nó hội tụ đủ các tính chất của một cấu trúc thủy động lực ven bờ, đặc biệt là có kích thước không-thời gian xác định. Luồng Nam - Bắc ven bờ vịnh đóng vai trò quyết định trong quá trình vận chuyển và tích tụ vật liệu đáy gây bồi lấp cửa.

Biện pháp xây đấp kè mỏ hàn chắn ngang phần trong cảng của luồng Nam-Bắc để chống nạn bồi lấp cửa, xét về mặt khoa học, là biện pháp hợp lý. Cơ chế động lực sau tác động của luồng chảy lên kè mỏ hàn bao gồm: - Sự uốn dòng đối với luồng ven bờ ở góc nối giữa bờ và kè, tiếp theo là định hướng luồng men theo mặt trước kè mà trong đó sự đóng góp của thành phần dòng do dao động va đập tạo ra làm cho cường độ luồng ở đây trở nên mạnh mẽ hơn; - Cơ chế tách dòng ở cuối kè thành hai nhánh, một nhánh có hướng xiên vào trong tiến đến mặt cắt cửa và eo cửa, nhánh kia xiên ra ngoài thâm nhập vào luồng lưu thông ven bờ Bắc vịnh. Toàn bộ cơ chế thủy động lực đó kéo theo quá trình vận chuyển vật liệu bồi tích từ phía Nam lên mà trong đó một lượng lớn được lắng đọng lại ở mặt trước kè mỏ hàn và một lượng không nhỏ khác trôi theo hai nhánh luồng ở cuối kè 
đưa vào bồi lấp cửa, eo cửa và luồng lưu thông.

Các kè mỏ hàn ở cửa $\mathrm{Sa}$ Huỳnh và Đề Gi được dựng lên bởi hai giai đoạn, giai đoạn đầu ngắn chừng $70-100 \mathrm{~m}$ và giai đoạn sau kéo dài thêm ra đến trên $200 \mathrm{~m}$, tuy nhiên cả hai đều không ngăn chặn được nạn bồi lấp cửa. Nguyên nhân là do cơ chế thủy-thạch động lực mới tạo ra do tác động của kè, đặc biệt là cơ chế tách dòng ở cuối kè, tiếp tục đưa vật liệu cát vào bồi lấp cửa, eo cửa và luồng ra vào của tàu thuyền ven bờ Bắc vịnh. Việc tăng chiều dài kè mỏ hàn ở giai đoạn sau không phá vỡ được cơ chế thủy-thạch động lực đó mà chỉ dẫn đến tình trạng biến đổi phức tạp hơn. Như vậy, các phương án dựng kè mỏ hàn đã không mang lại hiệu quả tốt. Riêng ở Tam Quan đã có kè mỏ hàn dài khoảng $300 \mathrm{~m}$ và người ta đang cố gắng xây dựng kéo dài ra hơn nữa, đến khoảng $750-800 \mathrm{~m}$, hiệu quả ngăn chặn nạn bồi lấp cửa Tam Quan thì chưa có gì đảm bảo chắc chắn.

\title{
TÀI LIỆU THAM KHẢO
}

1. Tô Quang Thịnh, Lê Phước Trình (Chủ biên) và nnk., 2000. Bộ Bản đồ xói lởbồi tụ bờ biển Việt Nam, 33 mảnh, tỷ lệ 1/100 000. Tư liệu kèm theo Báo cáo khoa học đề tài KHCN.06.08, Chương trình Biển cấp Nhà nước KHCN.06.

2. Lê Phước Trình (chủ biên), 2000. Nghiên cứu qui luật và dự đoán xu thế bồi tụ-xói lở vùng ven biển và cửa sông Việt Nam - Báo cáo khoa học tổng hợp Đề tài KHCN.06.08, Chương trình khoa học cấp Nhà nước KHCN.06, 88 trg.

3. Lê Phước Trình, 2008. Về khả năng tồn tại dòng rip tại các bãi biển miền Trung Báo cáo chuyên đề thuộc Đề tài "Nghiên cứu hiện tượng dòng rút (rip current) tại bãi biển Nha Trang - Cam Ranh”, Chủ nhiệm: TS Nguyễn Bá Xuân, Viện HDH, 32 trg.

4. Lê Phước Trình, Phan Quảng, Đặng Văn Hoan, 1995. Hệ dòng chảy ở vùng biển ven bờ miền Trung Việt Nam - Báo cáo khoa học đề tài cơ sở, Viện Hải dương học, Nha Trang, 29 trg.

THE PROBLEM OF DEPOSITION AT SA HUYNH (QUANG NGAI PROVINCE), TAM QUAN AND DE GI (BINH DINH PROVINCE) BY IMPACT ASSESSMENT OF TIDAL INLET PROTECTION STRUCTURES

\author{
PHAM BA TRUNG, LE DINH MAU, LE PHUOC TRINH
}

Summary: This paper presents some information about status and impact of protection structures on tidal inlet deposition processes at Sa Huynh (Quang Ngai Province); Tam Quan 
and De Gi (Binh Dinh Province) based on field investigation data. Study results show that the present measures of protection structures and its impacts on deposition processes at three above mentioned tidal inlets are similarly. Hydro-litho-dynamical processes in tidal inlets were changed and became more complicated by these protection structures, and they were not producing the desired effects.

Ngày nhận bài: 18 - 10 - 2009

Ngưòi nhận xét: GS. TS. Bùi Công Quế 